\title{
Forest fires in Canadian permafrost region: the combined effects of fire and permafrost dynamics on soil organic matter quality
}

\author{
Heidi Aaltonen $(\mathbb{D} \cdot$ Kajar Köster • Egle Köster • Frank Berninger • \\ Xuan Zhou - Kristiina Karhu • Christina Biasi • Viktor Bruckman • \\ Marjo Palviainen $\cdot$ Jukka Pumpanen
}

Received: 4 June 2018/ Accepted: 14 March 2019/Published online: 22 March 2019

(C) The Author(s) 2019

\begin{abstract}
Wildfires burn approximately $1 \%$ of boreal forest yearly, being one of the most significant factors affecting soil organic matter (SOM) pools. Boreal forests are largely situated in the permafrost zone, which contains half of global soil carbon (C). Wildfires advance thawing of permafrost by burning the insulating organic layer and decreasing surface albedo, thus increasing soil temperatures. Fires also affect SOM quality through chemical and physical changes, such as the formation of resistant $\mathrm{C}$
\end{abstract}

Responsible Editor: Edward Brzostek.

Electronic supplementary material The online version of this article (https://doi.org/10.1007/s10533-019-00560-x) contains supplementary material, which is available to authorized users.

H. Aaltonen $(\varangle) \cdot$ K. Köster · E. Köster ·

X. Zhou · K. Karhu $\cdot$ M. Palviainen

Department of Forest Sciences, University of Helsinki, PO Box 27, Latokartanonkaari 7, 00014 Helsinki, Finland e-mail: heidi.m.aaltonen@helsinki.fi

F. Berninger

Department of Environmental and Biological Sciences, University of Eastern Finland, PL 111, 80101 Joensuu, Finland

C. Biasi - J. Pumpanen

Department of Environmental and Biological Sciences, University of Eastern Finland, PL 1627, 70211 Kuopio, Finland compounds. The long-term post-fire effects on SOM quality, degradability and isotopic composition are not well known in permafrost forests. We studied the effect of forest fires on the proportional sizes of SOM pools with chemical fractionation (extracting with water, ethanol and acid) of soil samples (5, 30 and $50 \mathrm{~cm}$ depths) collected from a fire chronosequence in the upland mineral soils of the Canadian permafrost zone. We also determined the ${ }^{13} \mathrm{C}$ and ${ }^{15} \mathrm{~N}$ isotopic composition of soil after fire. In the topsoil horizon $(5 \mathrm{~cm})$ recent fire areas contained a smaller fraction of labile SOM and were slightly more enriched with ${ }^{15} \mathrm{~N}$ and ${ }^{13} \mathrm{C}$ than older fire areas. The SOM fraction ratios reverted towards pre-fire status with succession. Changes in SOM were less apparent deeper in the soil. Best predictors for the size of recalcitrant SOM

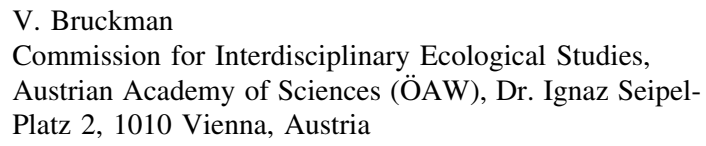


fraction were active layer depth, vegetation biomass and soil $\mathrm{C} / \mathrm{N}$ ratio, whereas microbial biomass was best predicted by the size of the recalcitrant SOM fraction. Results indicated that SOM in upland mineral soils at the permafrost surface could be mainly recalcitrant and its decomposition not particularly sensitive to changes resulting from fire.

Keywords Chemical fractionation $\cdot$ Microbial biomass - Wildfire

\section{Introduction}

Forest fires burn 5-20 M ha of boreal forest each year (Stocks et al. 2004; Sukhinin et al. 2004; Tan et al. 2007; Flannigan et al. 2009) and as much as $80 \%$ of the boreal forest region is located in the circumpolar permafrost zone (Helbig et al. 2016). Around half of the global soil carbon (C) pool resides in the permafrost soils of the Northern hemisphere and yet one-fourth of this permafrost is predicted to thaw by 2100 (Davidson and Janssens 2006). Thawing may be accelerated in multiple ways by fires; they not only release heat, but also may burn the insulating organic layer, leading to increased soil temperatures and, therefore, an increase in the active layer depth (Jorgenson et al. 2010; Bret-Harte et al. 2013; Brown et al. 2015; Gibson et al. 2018). Additionally, the albedo of the soil surface may change due to the destruction of vegetation and darkening of the soil surface (Bret-Harte et al. 2013; French et al. 2016). All of these factors can lead to further warming of the subsoil and thawing of permafrost (Yoshikawa et al. 2002; Randerson et al. 2006; Gibson et al. 2018). Thawing of permafrost means that soil organic matter (SOM) that was previously protected by subzero temperatures, becomes susceptible to decomposition (Dutta et al. 2006; Harden et al. 2012; Walz et al. 2017). The degree of SOM decomposition following permafrost thaw, and the resulting $\mathrm{CO}_{2}$ emissions, are still under discussion (Waldrop et al. 2010), and depend on many factors, such as soil hydrology (Trumbore and Harden 1997; Lawrence et al. 2015). The thawing permafrost has been expected to cause significant positive feedback to climate change through greenhouse gases released from decomposing, previously frozen organic matter (Schädel et al. 2016).
On the other hand, in forest areas, the succession of vegetation after a fire has been shown to protect the permafrost, even when air temperatures increase (Jorgenson et al. 2010).

Especially stand-replacing forest fires can produce large amounts of partly burnt organic material, which becomes incorporated to SOM (González-Pérez et al. 2004; López-Martín et al. 2016). This, together with the burning of the organic layer, may affect the soil microbial communities (Mataix-Solera et al. 2009). In general, forest fires decrease microbial biomass (Dooley and Treseder 2012; Köster et al. 2016), as even relatively low soil temperatures $\left(<100{ }^{\circ} \mathrm{C}\right)$ during the fire may be fatal to microbes (Certini 2005). Further, if the fire causes soil hydrophobicity, the soil may dry, further diminishing the microbial activity (DeBano 2000). The loss of SOM, in turn, can decrease the nutrient availability and microbial growth (Wan et al. 2001), which can lead to diminished decomposition of SOM in burnt forest areas (Debano and Conrad 1978; Certini et al. 2011). Conversely, a recent study from the Mediterranean has observed increased bacterial and fungal biomasses in burnt soils (Rodríguez et al. 2017, 2018).

Fire also affects physical and chemical properties of soil (Certini 2005; López-Martín et al. 2016). Burning causes significant C (Certini et al. 2011; De la Rosa et al. 2013) and nitrogen (N) loss from soil (Debano and Conrad 1978; Vitousek and Howarth 1991). During or after the fire the quality of SOM may decrease since the roots, and exudates emitted from them, are possibly removed and previously labile SOM may change its form (Waldrop et al. 2010; Schädel et al. 2016). This is also reflected in the soil $\mathrm{C} / \mathrm{N}$-ratio, which is usually reduced after fire (Almendros and González-Vila 2012). Possible changes that SOM may undergo during the fire are dependent on the chemical and physical properties of the soil, as well as the intensity of the fire (González-Pérez et al. 2004; Knicker 2007). For example, very high temperature leads to the production of black carbon (Waldrop et al. 2010; Almendros and González-Vila 2012). Black carbon usually has a long residence time in soil (Krull et al. 2006) and can therefore act as a C sink (Czimczik et al. 2003). It may also indirectly facilitate degradation of labile $\mathrm{C}$ by acting as a habitat for microbes (Wardle et al. 2008).

During forest fires, soil temperatures at the soil surface usually vary between 200 and $300{ }^{\circ} \mathrm{C}$, and 
even low temperatures of $40-70{ }^{\circ} \mathrm{C}$ cause degradation of biological material (Knicker 2007). Temperatures reaching $300{ }^{\circ} \mathrm{C}$ may cause structural changes in SOM, resulting in the formation of pyrogenic compounds (Almendros and Leal 1990; Knicker et al. 1996). Macromolecules, such as cellulose and lignin, may go through transformations during fire even at lower temperatures, leading to the formation of compounds, which are more recalcitrant and thus become unrecognisable to certain enzymes (Almendros and González-Vila 2012). Furthermore, chemical changes in SOM functional groups may lead to hydrophobicity or stronger binding of SOM to mineral particles (Faria et al. 2012). This means that post-fire a certain amount of SOM becomes protected from microbial degradation (Faria et al. 2012). In summary, there could be significant, yet bidirectional impacts of forest fire on SOM decomposition in permafrost regions, with the overall short- and long-term impacts remaining yet unknown.

The isotopic composition of SOM may be used to describe SOM lability as processed, recalcitrant SOM, typically is enriched with heavier isotopes compared to fresh SOM (Natelhoffer and Fry 1988; Wynn 2007). The enrichment is mainly caused by microbial degradation of organic matter (Natelhoffer and Fry 1988; Ehleringer et al. 2000), but also other processes, such as differing mobility of dissolved organic compounds, may have a role in the enrichment (Ehleringer et al. 2000; Tu et al. 2004). In these processes, the heavier isotopes are left behind since they require higher activation energy in reactions (Wynn 2007). Wildfires have been found to enrich soil with ${ }^{15} \mathrm{~N}$ to lighter ${ }^{14} \mathrm{~N}$ (Cook 2001; Boeckx et al. 2005), which is caused by discrimination against heavier isotopes during volatilization of N (Frank et al. 2004) or nitrification process (Pardo et al. 2002). On the other hand, isotopic enrichment of soil may also be dependent on the burning of depleted litter during the fire (Högberg 1997). The effects of fire on soil $\delta{ }^{13} \mathrm{C}$ composition are not as consistent with studies reporting depletion, while some found no clear effect and some enrichment (Beuning and Scott 2002; Rumpel et al. 2007; Hyodo et al. 2013).

Several recent studies have focused on the degradability and quality of permafrost SOM (Dutta et al. 2006; Waldrop et al. 2010; Moni et al. 2015; Weiss et al. 2016; Walz et al. 2017). Nevertheless, studies concentrating on different SOM fractions in permafrost areas are rare (Dutta et al. 2006; Höfle et al. 2013; Gentsch et al. 2015). To our knowledge, studies utilising chemical fractionation to study the quality of SOM in fire-affected permafrost forest soils are lacking. As forest fires and quality of SOM have significant effects on the release of $\mathrm{C}$ from forest covered permafrost soils, it is crucial for future predictions of possible $\mathrm{CO}_{2}$ emissions to understand how fires change the proportions of different SOM fractions, as well as how permafrost SOM is generally divided between these fractions.

The aim of this study was to examine how the proportions of insoluble (recalcitrant) and soluble (labile) fractions in SOM change as a result of forest fire in the active layer on permafrost. We also aimed to study how the abundancies of stable isotopes $\delta^{15} \mathrm{~N}$ and $\delta{ }^{13} \mathrm{C}$ change along with depth and time since last fire. Our final aim was to identify the most important factors (active layer depth, soil temperature, biomass, $\mathrm{C} / \mathrm{N}$ ratio) explaining the size of insoluble (recalcitrant) fractions of SOM post-fire, as well as to determine the SOM fractions most affecting the microbial biomass.

We hypothesised that the effects of fire could be seen in the composition of different chemical SOM fractions, as fire may decrease the amount of SOM, while at the same time also releasing organic matter from burning vegetation (possibly increasing the proportion of labile SOM) and on the other hand forming recalcitrant compounds (increasing the proportion of recalcitrant SOM). We also expected the changes in the proportions of the different chemical SOM fractions to be apparent along the fire chronosequence with advancing succession after fire. These changes could be observed as a larger fraction of recalcitrant SOM after the fire and comparably larger fractions of more labile SOM as succession proceeds and the effects of fire are diminishing with time. Also, we expected the fire to cause changes in the isotopic composition of SOM, as for ${ }^{15} \mathrm{~N}$ there may be discrimination during volatilisation of $\mathrm{N}$ (Frank et al. 2004), while the effects of fire on $\delta{ }^{13} \mathrm{C}$ are not as clear (Beuning and Scott 2002; Rumpel et al. 2007; Hyodo et al. 2013). 


\section{Materials and methods}

Study sites and sample collection

The study sites were located in the northern boreal forests of Canada (Fig. S1, Online resource), along the Dempster Highway close to Eagle Plains, Yukon $\left(66^{\circ} 22^{\prime} \mathrm{N}, 136^{\circ} 43^{\prime} \mathrm{W}\right)$, and Tsiigehtchic, Northwest Territories $\left(67^{\circ} 26^{\prime} \mathrm{N}, 133^{\circ} 45^{\prime} \mathrm{W}\right)$, also described in Köster et al. (2017). This area belongs to the taiga zone, with annual mean temperature and precipitation of $-8.8{ }^{\circ} \mathrm{C}$ and $248 \mathrm{~mm}$, respectively (Environment and Climate Change Canada 2017). The location is characterised by underlying, continuous permafrost. The permafrost area is affected by cryoturbation and soils are classified as cryosols (IUSS Working Group WRB 2014), or relict cryosols in the youngest fire area. The dominating soil texture was silt loam. The tree species in the area consist mainly of evergreen conifers, such as Picea mariana (Mill.) BSP and some Picea glauca (Moench) Voss. The ground vegetation is mostly formed by the following species: Sphagnum sp., Cladonia sp., Cladina sp., L., Rhododendron groenlandicum Oeder., Rubus chamaemorus L. and Vaccinium uliginosum $\mathrm{L}$.

We established the study areas in 2015 in forest areas burnt $3\left(\mathrm{FIRE}_{3}\right), 25\left(\mathrm{FIRE}_{25}\right), 46\left(\mathrm{FIRE}_{46}\right)$ and over 100 years ago $\left(\right.$ FIRE $\left._{100}\right)$, so that together they formed a fire chronosequence, as also described in Köster et al. (2017) (Fig. S1, Online resource). Fire areas forming the chronosequence were selected from unmanaged areas based on year of fire and reachability. These study areas were located based on GIS-maps of burnt areas in Yukon and Northwest Territories and further narrowed down during fieldwork based on finding areas with similar soil type, topography, tree species and tree diameter. Stand ages were confirmed from cored tree rings. Each fire area had three sample lines (length $150 \mathrm{~m}$ ), with each line having three sample plots $(\mathrm{n}=9) 50 \mathrm{~m}$ apart from each other in FIRE $_{3}$, FIRE $_{25}$ and FIRE 46 . The lines were separated by a minimum of $200 \mathrm{~m}$ and they were placed at least $150 \mathrm{~m}$ away from roads to avoid any effects of roads on vegetation or permafrost depth (Gill et al. 2014). For comparison, we also established a similar $150 \mathrm{~m}$ long line (with three sampling plots in each) in a forest stand that had not been exposed to fire in the last 100 years. These lines were situated next to $\mathrm{FIRE}_{3}$, FIRE $_{25}$ and FIRE 46 , one line next to each area, to represent the possible spatial geographical variation and to achieve a balanced comparison between fire areas in the analysis. These three lines together formed the area $\left(\mathrm{FIRE}_{100}\right)$ used in the analysis.

Soil samples were taken from soil pits, excavated on each sample plot, by inserting a cylinder $(6 \mathrm{~cm}$ diameter and length) horizontally into the soil profile. Samples were collected from the depths of 5, 30 and $50 \mathrm{~cm}$ so that the point of sampling depth was at the center of the cylinder. Samples were then frozen until analysis. The soil temperature (Table S1, Online resource) for each sampling depth was measured from the pit excavated in each sampling plot. The active layer depth was measured simultaneously from each pit or, when deeper than $1.2 \mathrm{~m}$, estimated by using a linear regression of soil temperature against the soil depths. Sampling depth of $50 \mathrm{~cm}$ was below permafrost layer in $\mathrm{FIRE}_{46}$ and $\mathrm{FIRE}_{100}$ areas (where also $30 \mathrm{~cm}$ sampling depth was just below the permafrost surface). The permafrost depths, together with other basic soil characteristics are presented in Table $\mathrm{S} 1$ and S2 (Online Resource).

Biomass for each area was also estimated by determining the tree and ground vegetation biomass (Table S2, Online resource) as described by Köster et al. (2017) in each plot. The ground vegetation biomass was measured from four $0.20 \times 0.20 \mathrm{~m}^{2}$ in each plot, while ground vegetation coverage was visually determined from two $0.75 \times 0.75 \mathrm{~m}^{2}$. We also measured tree characteristics from a $400 \mathrm{~m}^{2}$ area for all trees over $1 \mathrm{~m}$ tall: stem diameter at $1.3 \mathrm{~m}$ height (or diameter at the base of trees shorter than $1.3 \mathrm{~m}$ in height), the height of a tree, crown height and crown diameter. Tree biomass was calculated following the allometric functions (Lambert et al. 2005) with a separate function for spruce (Wagner and TerMikaelian 1999).

\section{Soil chemical fractionation}

SOM quality was studied by using chemical fractionation following Berg and Ekbohm (1991) and Karhu et al. (2010) in which oven dried $\left(40{ }^{\circ} \mathrm{C}\right)$ soil samples were separated into water (sugars, low levels of fatty acids and protein remains), ethanol (waxes, fats), sulphuric acid hydrolysable (hemicellulose, cellulose) and non-hydrolysable (Klason lignin and humified material) fractions (Berg and McClaugherty 2003; Trofymow and Group 1998). First, the soil-extraction 
solutions were sonicated for $90 \mathrm{~min}$ in a water bath, after which the solution was filtered through glass crucibles (Schott Duran, pore size $10 \mu \mathrm{m}$ ) and oven dried at $105{ }^{\circ} \mathrm{C}$. Dried samples were weighed using an analytical scale, with detected mass loss indicating the water-soluble fraction. Extraction was repeated accordingly with pure ethanol. Lastly, the remaining sample was extracted in $72 \%$ sulphuric acid, whereby the acid solution was sonicated for $60 \mathrm{~min}$ and the solution was diluted to $2.5 \%$ and autoclaved for $60 \mathrm{~min}$ at $125{ }^{\circ} \mathrm{C}$. After autoclaving the samples were filtered, rinsed with ultrapure water, and dried as in the previous extractions. Mineral soils (30 and $50 \mathrm{~cm}$ ) were extracted the same way as the organic soils but, due to fine soil particles, the samples were centrifuged in glass tubes instead of filtering through crucibles. SOM content was determined as loss on ignition $\left(550{ }^{\circ} \mathrm{C}, 3 \mathrm{~h}\right)$ and the different soil fractions are expressed as a percent off total SOM. The different SOM fractions can be connected to corresponding SOM pools characterized by their turnover times: active pool (sugars), slow pool (waxes, fats, cellulose) and very slow/stable pool (lignin) (Bot and Benites 2005).

\section{Determination of soil characteristics}

The $\mathrm{pH}$ and electric conductivity of the soil (Table S1, Online resource) were determined from a 1:2.5 (v:v) soil/water solution that was left to settle overnight. The measurements were performed with a $\mathrm{pH}$ meter (PHM210, Radiometer Analytical, France) and an electric meter (JENWAY 4010 Conductivity, TER Calibration Ltd., Wigan, UK). Further, we measured soil particle size distribution for soil classification from oven dried, sieved $(<2 \mathrm{~mm})$ samples with laser diffraction (LS 230, Beckman Coulter Inc. US).

Soil $\mathrm{C}$ and $\mathrm{N}$ concentrations (Table 1) and natural isotope abundances $\left(\delta{ }^{15} \mathrm{~N}\right.$ and $\left.\delta{ }^{13} \mathrm{C}\right)$ were analysed from bulk soil. Subsamples were ground to fine powder and approximately $3 \mathrm{mg}$ was packed into tin capsules. The analyses were performed with an elemental analyser (FlashEA 1112 Series, Thermo Fischer Scientific, Waltham, MA) coupled to an isotope ratio mass spectrometer (IRMS, DELTA plusXP ${ }^{\odot}$, Thermo Electron Fischer Scientific, Waltham, MA). The isotopic values $\left({ }^{13} \mathrm{C} /{ }^{12} \mathrm{C}\right.$ and ${ }^{15} \mathrm{~N} /{ }^{14} \mathrm{~N}$ ratios) are expressed as milli-Urey (mUR) in relation to international reference standards (Peedee Belemnite for ${ }^{13} \mathrm{C} /{ }^{12} \mathrm{C}$ and air for ${ }^{15} \mathrm{~N} /{ }^{14} \mathrm{~N}$ ) determined as:

$\delta X=\left[\left(R_{S} / R_{s d}\right)-1\right] \times 1000$

where $X$ is the isotope, $R_{\mathrm{s}}$ is the isotope ratio of the sample (heavy to light), and $R_{\mathrm{sd}}$ is the ratio of the international reference standard. More details on the isotope analysis are found in Figueiredo et al. (2014).

\section{Microbial biomass carbon}

We also determined the microbial biomass $\mathrm{C}$ following the fumigation-extraction method by Vance et al. (1987). The extracted microbial C was measured with total organic C analyzer (TOC-V CPH, Shimadzu, Kyoto, Japan) and calculated as described by Beck et al. (1997). Here the microbial biomass also includes the fungal biomass.

\section{Statistical analyses}

We used linear mixed effects model for statistical analyses of the data. The analyses were performed using R (i386 3.3.2) with the lme4 package (Bates et al. 2015) and drop1-function (Chambers and Hastie 1992). Differences in fractions and isotopes between the age classes (or soil depths) were tested with multiple comparison of means, using the Tukey's HSD post hoc test. The fixed factor was either time since fire or soil depth (depending on if the analysis was comparing time since fire or soil depths). Sampling lines were treated as true replicates (random effects). Data was tested for normality of residuals with the Shapiro-Wilk's test, and in case of percentage values, transformed with the arcsine-transformation to meet the criteria of the tests. Linear mixed effects model was also utilised to determine the factors most affecting the size of the insoluble organic fraction in the soil. The best model was selected based on the Akaike's information criterion (AIC) (Chambers and Hastie 1992). This was achieved by dropping fixed factors from the model based on their AICvalues. The same model (Eq. 2) was fitted against the insoluble SOM fraction separately for each depth. The initial model was:

$$
\begin{aligned}
S O M_{\text {non }}= & a+b A D+c \text { Biomass }+d T+e(T \times A D) \\
& +f C N+g R D M
\end{aligned}
$$


Table 1 Mean $( \pm$ SE) soil organic matter carbon and nitrogen concentrations and the $\mathrm{C} / \mathrm{N}-$ ratios $(\mathrm{n}=9)$

\begin{tabular}{lclllll}
\hline Area & $\begin{array}{l}\text { Depth }(\mathrm{cm}) \\
(\mathrm{cm})\end{array}$ & $\mathrm{C} \mathrm{kg} \mathrm{m}^{-2}$ & $\mathrm{C}(\%)$ & $\mathrm{N}(\%)$ & C/N-ratio & Soil type \\
\hline FIRE $_{3}$ & 5 & $2.61 \pm 0.5$ & $42.8 \pm 7.69$ & $1.1 \pm 0.2$ & $38.1 \pm 2.4$ & Organic \\
& 30 & $7.74 \pm 1.2$ & $4.80 \pm 1.51$ & $0.3 \pm 0.1$ & $15.4 \pm 2.4$ & Mineral \\
& 50 & $3.92 \pm 0.3$ & $2.90 \pm 0.60$ & $0.2 \pm 0.0$ & $15.9 \pm 1.3$ & Mineral \\
FIRE $_{25}$ & 5 & $7.46 \pm 3.7$ & $33.5 \pm 6.89$ & $0.8 \pm 0.1$ & $44.7 \pm 9.3$ & Organic \\
& 30 & $8.64 \pm 1.3$ & $9.33 \pm 4.30$ & $0.4 \pm 0.1$ & $18.5 \pm 1.8$ & Mineral \\
& 50 & $2.57 \pm 0.4$ & $2.38 \pm 0.78$ & $0.2 \pm 0.1$ & $12.5 \pm 2.0$ & Mineral \\
FIRE $_{46}$ & 5 & $5.27 \pm 1.3$ & $42.3 \pm 3.42$ & $1.4 \pm 0.0$ & $30.4 \pm 1.2$ & Organic \\
& 30 & $7.17 \pm 1.9$ & $3.97 \pm 0.86$ & $0.3 \pm 0.0$ & $14.8 \pm 0.9$ & Mineral \\
& 50 & $4.42 \pm 0.8$ & $4.44 \pm 0.95$ & $0.4 \pm 0.1$ & $12.9 \pm 1.5$ & Mineral \\
FIRE $_{100}$ & 5 & $7.09 \pm 1.4$ & $38.9 \pm 2.43$ & $1.1 \pm 0.2$ & $48.4 \pm 4.1$ & Organic \\
& 30 & $6.40 \pm 1.0$ & $8.74 \pm 3.02$ & $0.6 \pm 0.2$ & $13.7 \pm 1.6$ & Mineral \\
& 50 & $1.28 \pm 0.2$ & $3.79 \pm 0.87$ & $0.3 \pm 0.1$ & $15.1 \pm 2.7$ & Mineral \\
\hline
\end{tabular}

where $a$ is the intercept of the model and parameters from $b$ to $g$ are regression coefficients for the factors. The following fixed factors were used in the models: $A D(\mathrm{~m})$ is the depth of the active layer, Biomass $\left(\mathrm{kg} \mathrm{m}^{-2}\right)$ is the above ground biomass consisting of tree and ground vegetation (shrubs, grasses, mosses and lichens), $T\left({ }^{\circ} \mathrm{C}\right)$ is soil temperature at the time of sampling in each soil depth, $A D \times T$ is the cross effect of active layer depth and soil temperature and $C N(\%)$ is the soil $\mathrm{C} / \mathrm{N}$ ratio. Sampling line was set as a random factor $R D M$. The factors and models are further described in Table 2. Time since fire was not included in the model as it correlates with $A D$ and Biomass and its effects are apparent already through these factors.

The best model for each soil depth was selected for sensitivity analyses of the variables. The sensitivity analyses were performed to determine how much the change of factors in the best fitting model would affect the predicted $S O M_{\text {non }}$. This was conducted using mean values for each factor and changing one factor at a time by $\pm 10 \%$, while others remained unchanged. With every change, value for $S O M_{n o n}$ was calculated

Table 2 Linear mixed effects models fitted against the insoluble SOM fraction $\left(S O M_{n o n}\right)$ and experimental factors separately for each sampling depth $(5,30,50 \mathrm{~cm})$

\begin{tabular}{|c|c|c|}
\hline Model ID & Mixed effect model & Depth $(\mathrm{cm})$ \\
\hline Model 1 (initial model) & $S O M_{\text {non }}=a+b A D+c$ Biomass $+d T+e(T \times A D)+f C N+g R D M$ & \\
\hline Model 2 & $S O M_{\text {non }}=a+b A D+c$ Biomass $+d T+f C N+g R D M$ & 5 \\
\hline Model 3 & $S O M_{n o n}=a+b A D+c$ Biomass $+f C N+g R D M$ & 5 \\
\hline Model 4 & $S O M_{n o n}=a+b A D+c B i o m a s s+g R D M$ & 5 \\
\hline Model 2b & $S O M_{\text {non }}=a+b A D+$ cBiomass $+d T+f C N+g R D M$ & 30 \\
\hline Model 3b & $S O M_{n o n}=a+b A D+$ cBiomass $+f C N+g R D M$ & 30 \\
\hline Model 4b & $S O M_{n o n}=a+c$ Biomass $+f C N+g R D M$ & 30 \\
\hline Model 2c & $S O M_{n o n}=a+b A D+d T+e(T \times A D)+f C N+g R D M$ & 50 \\
\hline Model 3c & $S O M_{\text {non }}=a+b A D+d T f+C N+g R D M$ & 50 \\
\hline Model 4c & $S O M_{n o n}=a+b A D+f C N+g R D M$ & 50 \\
\hline Model 5c & $S O M_{n o n}=a+f C N+g R D M$ & 50 \\
\hline
\end{tabular}

The best-fitted model for each depth is highlighted with bold lettering. Fixed factors are: $A D=$ depth of the active layer, Biomass $=$ total biomass of trees and ground vegetation, $\mathrm{T}$ is soil temperature, $\mathrm{AD} \times \mathrm{T}$ is the cross effect of active layer depth and soil temperature and $\mathrm{CN}$ is soil carbon to nitrogen ratio. RDM is the random factor (sampling line) 
using Eq. 2 and compared to a value where none of the factors were changed.

In addition, we compared different fractions as explaining factors for Microbial C (Eq. 3). Due to the fractions being dependent on each other, the model included only one fraction at a time and sampling line as a random factor. The best describing factor was chosen based on model $P$ value and pseudo $\mathrm{R}^{2}$.

$M C=a+$ bFaction $+c R D M$

where $a$ is the intercept, $b$ and $c$ are regression coefficients, $M C$ is the microbial carbon $\left(\mathrm{mg} \mathrm{g}^{-1}\right)$, Fraction is the size (\%) of the fraction (water-, ethanol-, acid-soluble, or insoluble) and $R D M$ is the random factor (sampling line).

\section{Results}

Soil organic matter fractions

Generally, the soil layers differed significantly in terms of the proportions of insoluble and soluble SOM fractions (Fig. 1). At $5 \mathrm{~cm}$ depth, the soluble fractions together formed on average $65 \%$ of SOM and the insoluble fraction around 35\%, whereas at the $30 \mathrm{~cm}$ and $50 \mathrm{~cm}$ depths the insoluble fraction constituted to $75-84 \%$ of SOM and soluble fractions together only $16-25 \%$.

The fire had effects on the size of the water- and ethanol-soluble fractions in the surface soil $(5 \mathrm{~cm})$ (Table S3, Online resource). These fractions were smallest mainly shortly after the fire and increased along with the forest succession. At $5 \mathrm{~cm}$ depth (Fig. 1a), areas FIRE $_{25}$ and FIRE $_{46}$ had a larger proportion of water-soluble SOM than area $\mathrm{FIRE}_{3}$ $(\mathrm{P}<0.05)$, but there was no difference between area FIRE $_{100}$ and area FIRE 3 . In addition, the FIRE 46 area had higher water-soluble fraction than the FIRE 100 area $(\mathrm{P}<0.05)$. Both younger fire areas, $\mathrm{FIRE}_{3}$ and FIRE $_{25}$, had a smaller ethanol-soluble fraction than the older fire areas $(\mathrm{P}<0.001)$. Further, the acid-soluble fraction and the insoluble fraction were not significantly different between fire ages, though there was a tendency towards an increase in the more recently burnt areas. P-values for comparison between fire ages at all depths are given in more detail in tables S3-S5 (Online Resource).
Deeper in the soil, the changes in SOM fractions along with the fire chronosequence were not as consistent as at the surface. In the $30 \mathrm{~cm}$ layer (Fig. 1b), area FIRE $_{46}$ had a larger water-soluble fraction than all the other areas $(\mathrm{P}<0.001)$ (Table S4, Online resource). In addition, area $\mathrm{FIRE}_{100}$ had a larger ethanol-soluble fraction than $\mathrm{FIRE}_{25}$ and $\mathrm{FIRE}_{3}$ $(\mathrm{P}<0.05)$. The $30 \mathrm{~cm}$ layer also deviated from the two other layers in the size of the acid-soluble and insoluble fractions (Fig. 1b). Both FIRE 100 and FIRE areas had greater acid-soluble fraction than areas FIRE $_{25}$ and FIRE $_{46}(\mathrm{P}<0.001)$, with FIRE $_{46}$ having a larger acid-soluble fraction than $\operatorname{FIRE}_{25}(\mathrm{P}<0.05)$. Area FIRE 25 had a larger insoluble fraction than any of the other areas $(\mathrm{P}<0.001)$. In the $50 \mathrm{~cm}$ layer (Fig. 1c), the only differences were in the ethanolsoluble fraction where area FIRE 46 showed larger values than $\mathrm{FIRE}_{100}$ and $\mathrm{FIRE}_{3}(\mathrm{P}<0.001)$, while in FIRE $_{25}$ the ethanol-soluble fraction was larger than in area FIRE $_{100}(\mathrm{P}<0.001)$ (Table S5, Online resource). The approximated amounts of each fraction from total soil $\mathrm{C}$ values $\left(\mathrm{kg} \mathrm{m}^{-2}\right)$ varied with soil depth e.g. water-soluble fraction at the $5 \mathrm{~cm}$ depth was $0.13-0.43 \mathrm{~kg} \mathrm{~m}^{-2}$ and at $50 \mathrm{~cm}$ depth $0.02-0.15 \mathrm{~kg} \mathrm{~m}^{-2}$ (Table S6, Online Resource). For areas FIRE $_{46}$ and FIRE $_{100}$ this depth represents permafrost SOM.

$\delta{ }^{15} \mathrm{~N}$ and $\delta{ }^{13} \mathrm{C}$ in bulk soil

In general, fire seems to have had an age- but no depthwise effect on the soil ${ }^{15} \mathrm{~N}$ isotopic values. The agerelated trend in $\delta^{15} \mathrm{~N}$-values (Fig. 2a) appeared at $5 \mathrm{~cm}$ with the $\mathrm{FIRE}_{3}$ area being more enriched compared to area $\operatorname{FIRE}_{100}(\mathrm{P}<0.05)$. The pattern was similar, though only marginally so $(\mathrm{P}=0.063)$, at $30 \mathrm{~cm}$ depth (Fig. 2b). At $50 \mathrm{~cm}$ depth there were no significant differences (Fig. 2c). Moreover, we found no significant differences when we compared the ${ }^{15} \mathrm{~N}$ $\delta$-values between depths for each fire age.

The $\delta{ }^{13} \mathrm{C}$ values showed that the $5 \mathrm{~cm}$ depth was less depleted in $\delta{ }^{13} \mathrm{C}(\mathrm{P}<0.05)$ in the more recently burnt areas $\left(\mathrm{FIRE}_{3}\right.$ and $\left.\mathrm{FIRE}_{25}\right)$ than in the older areas $\left(\mathrm{FIRE}_{100}\right.$ and FIRE 46$)$. Yet, there was no difference between areas FIRE $_{25}$ and $\mathrm{FIRE}_{3}$. At $30 \mathrm{~cm}$ depth (Fig. 3b) area FIRE 46 was more enriched in ${ }^{13} \mathrm{C}$ than all the other areas $(\mathrm{P}<0.05)$. At $50 \mathrm{~cm}$ depth (Fig. 3c), we found no statistical differences. Contrastingly to $\delta^{15} \mathrm{~N}$, the $\delta^{13} \mathrm{C}$-values (Fig. 3a) were 
Fig. 1 The mean chemical fractions of SOM from the 5, 30 and 50 sampling depths, presented as a percentage of total SOM. The error bars show standard errors of mean
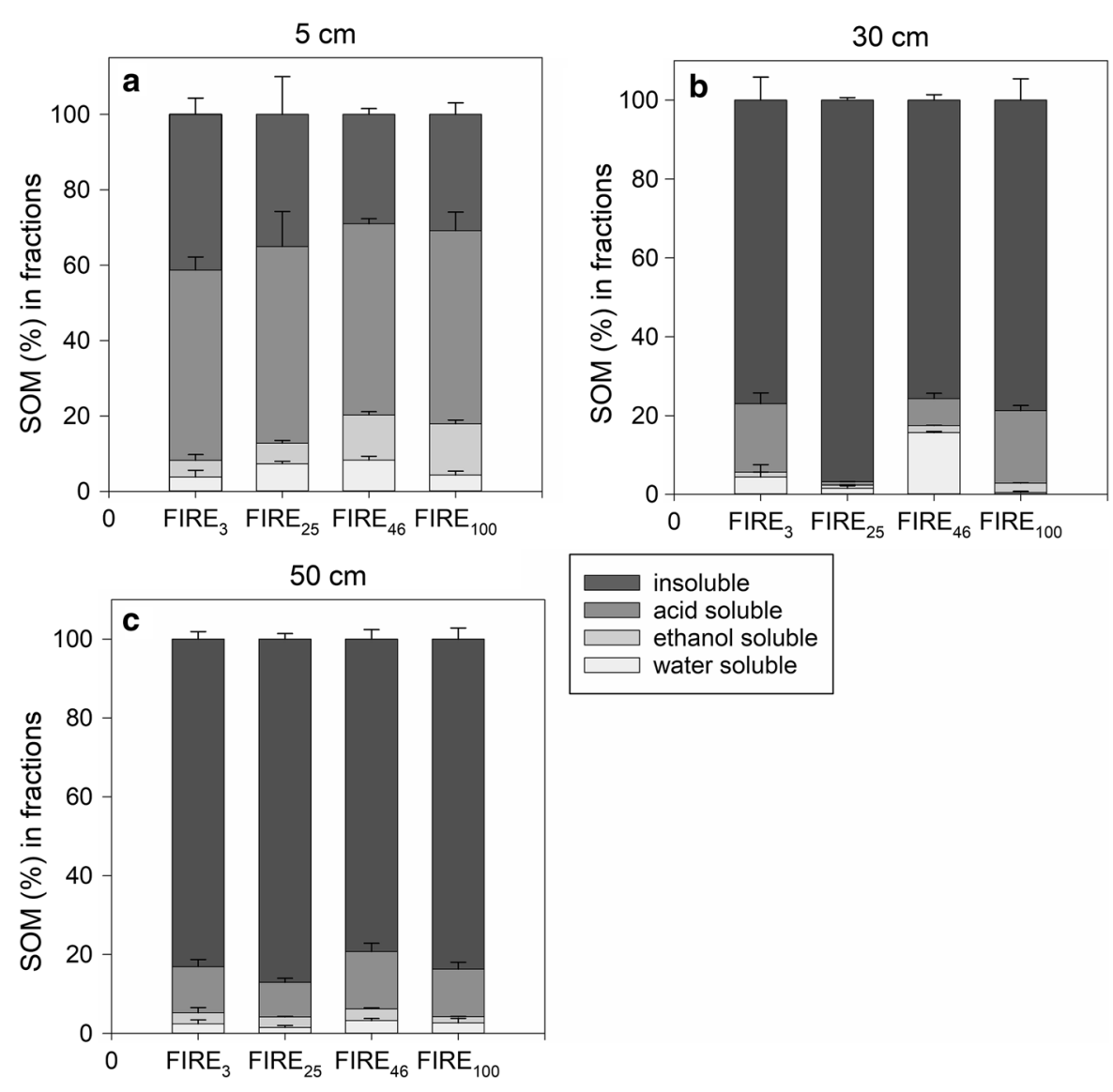

significantly more depleted in the $5 \mathrm{~cm}(\mathrm{P}<0.001)$ layer than in the 30 and $50 \mathrm{~cm}$ layers. Also, in general, we found no significant differences in total soil $\mathrm{C}$ and $\mathrm{N}$ concentrations or $\mathrm{C} / \mathrm{N}$ ratio between fire ages $(\mathrm{P}>0.05)$.

\section{Linear mixed effects model analyses}

Based on the linear mixed effect model analyses (Table 2), the size of the insoluble SOM fraction at $5 \mathrm{~cm}$ depth was best explained by the active layer depth and biomass (Model 4), which together explained $22 \%$ of the variation in the size of the fractions (Table S7, Online resource). At $30 \mathrm{~cm}$ depth the best explaining factors were biomass and $\mathrm{C} / \mathrm{N}$ ratio (Model 4b), explaining $85 \%$ of the variation (Table S8, Online resource). At $50 \mathrm{~cm}$ depth, the best model (Model 5c), including only $C / N$, could explain $10 \%$ of the insoluble SOM fraction size (Table S9, Online resource).
Microbial C was best predicted by the size of the insoluble fraction at the 5 and $30 \mathrm{~cm}$ depths (Table S10, Online resource). At $5 \mathrm{~cm}$ depth the insoluble fraction explained $27 \%$ of the microbial $\mathrm{C}$ $(\mathrm{P}=0.046)$, while at $30 \mathrm{~cm}$ depth $(\mathrm{P}<0.001)$ it explained $97 \%$. The size of the insoluble fraction and microbial biomass seem to have a negative correlation (Table S10, Online Resource). Still, at $50 \mathrm{~cm}$ depth none of the models were significant.

Sensitivity analyses of the best model (Model 4) at $5 \mathrm{~cm}$ soil depth revealed that changing either of the variables ( $A D$ or Biomass) results in a change of 1.5$2.0 \%$ in the size of the insoluble SOM fraction (Fig. S2, Online resource). The model was most sensitive to changes in the biomass. At $30 \mathrm{~cm}$ depth, where best model was $4 \mathrm{~b}$, the resulting change in insoluble SOM fraction size would be $0.1-0.6 \%$ (Fig. S2, Online resource) with the model again being most sensitive to changes in the biomass. Finally, at $50 \mathrm{~cm}$ soil depth (Model 5c) a change in the $\mathrm{C} / \mathrm{N}$ ratio 
Fig. 2 The natural $\delta^{15} \mathrm{~N}$ values of bulk soil samples at 5,30 and $50 \mathrm{~cm}$ depths from each fire area. The letters denote significant differences between age classes
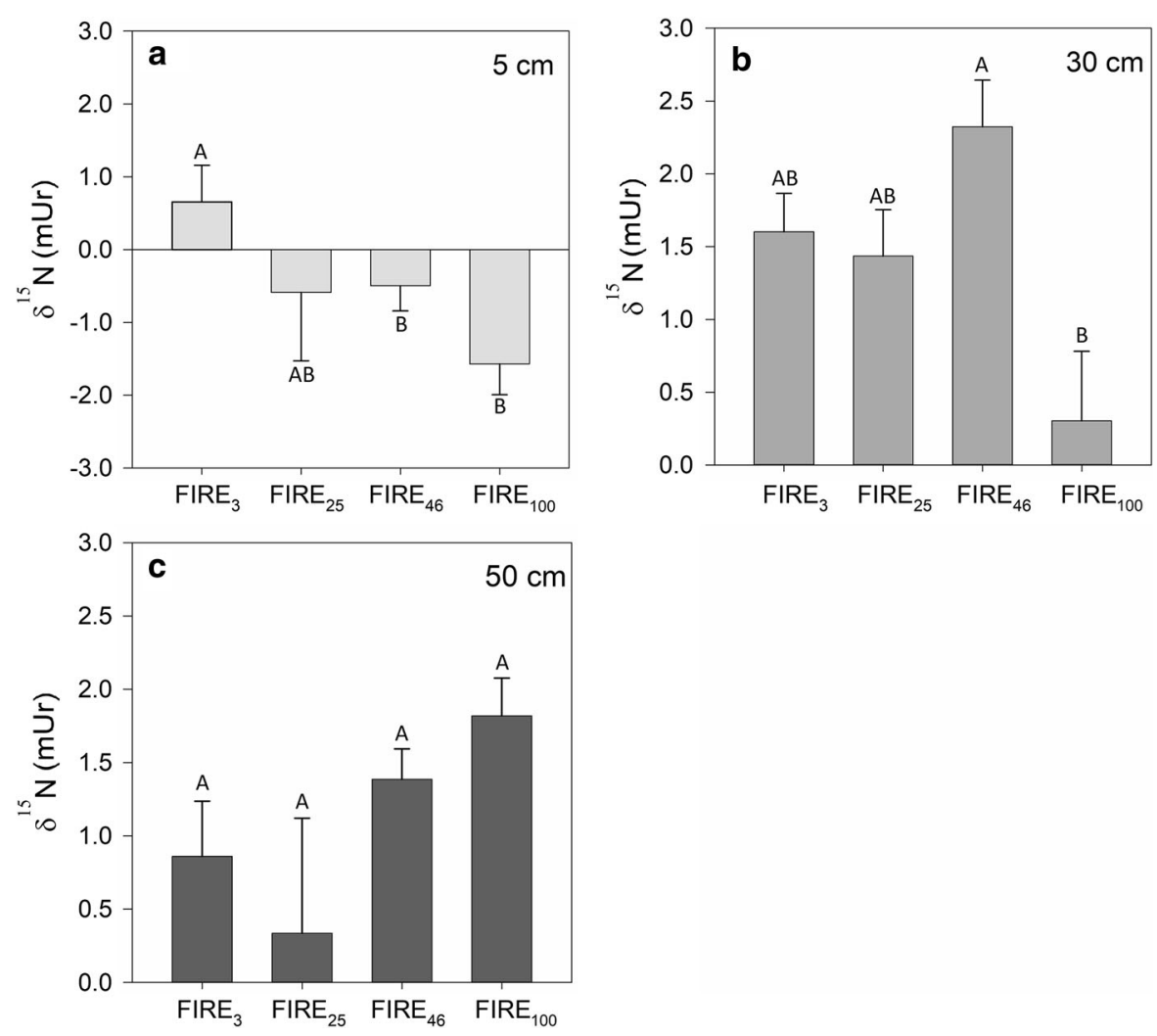

leads to a $1.2 \%$ change in the insoluble SOM fraction (Fig. S2, Online resource).

\section{Discussion}

The increased frequency of forest fires decreases both the ability of forests to store $\mathrm{C}$ and the degree of permafrost recovery (Hoy et al. 2016). Therefore, effects of fire on SOM quality, microbial activity and permafrost thaw could have a significant effect on greenhouse gas emissions during fire intervals. Our results indicated that the proportional sizes of the most soluble fractions (water and ethanol) in the surface soil (5 cm depth) were in general smaller after fire and increased with time. However, changes were not consistent in the two deepest layers. It may be that the effects of fire do not reach to depths of 30 and $50 \mathrm{~cm}$, although fire has clearly changed the active layer depth (Köster et al. 2017), exposing previously frozen soil at $50 \mathrm{~cm}$ to thaw. Also study by Shibata et al. (2003) noted that fire did not affect the water-extractable $\mathrm{C}$ in the mineral soil.
The different SOM fractions can be thought to represent different SOM pools with differing turnover times. These SOM pools are decomposing with different rates in the soil and can be roughly divided from fast to slow in following order: sugars, starches, simple proteins, crude proteins, hemicellulose, cellulose, fats, waxes, resins and lignins (Osman 2013). Also decomposition models, such as Yasso and CENTURY, often divide SOM into pools, based on their turnover times. Yasso divides decomposing material to extractives, celluloses, lignin-like materials, humus 1 and humus 2 (Liski et al. 2005). In these pools the water-and ethanol extractable SOM could be though to belong to the extractives pool with a decomposition rate of 0.48 year $^{-1}$ (rates for conifer litter). The decomposition rate for cellulose is 0.30 year $^{-1}$ and lignin-like compounds 0.22 year $^{-1}$, while humus 1 pool has a decomposition rate of 0.012 year $^{-1}$ and humus 2 pool 0.0012 year $^{-1}$ (Liski et al. 2005). In CENTURY the pools are divided to active pool (turnover time of months to few years), slow pool (turnover time of 20-50 years) and stable pool (turnover time of 400-2000 years) 
Fig. 3 The natural $\delta^{13} \mathrm{C}$ values of bulk soil samples at 5, 30 and $50 \mathrm{~cm}$ depths from each fire area. The letters denote significant differences between age classes
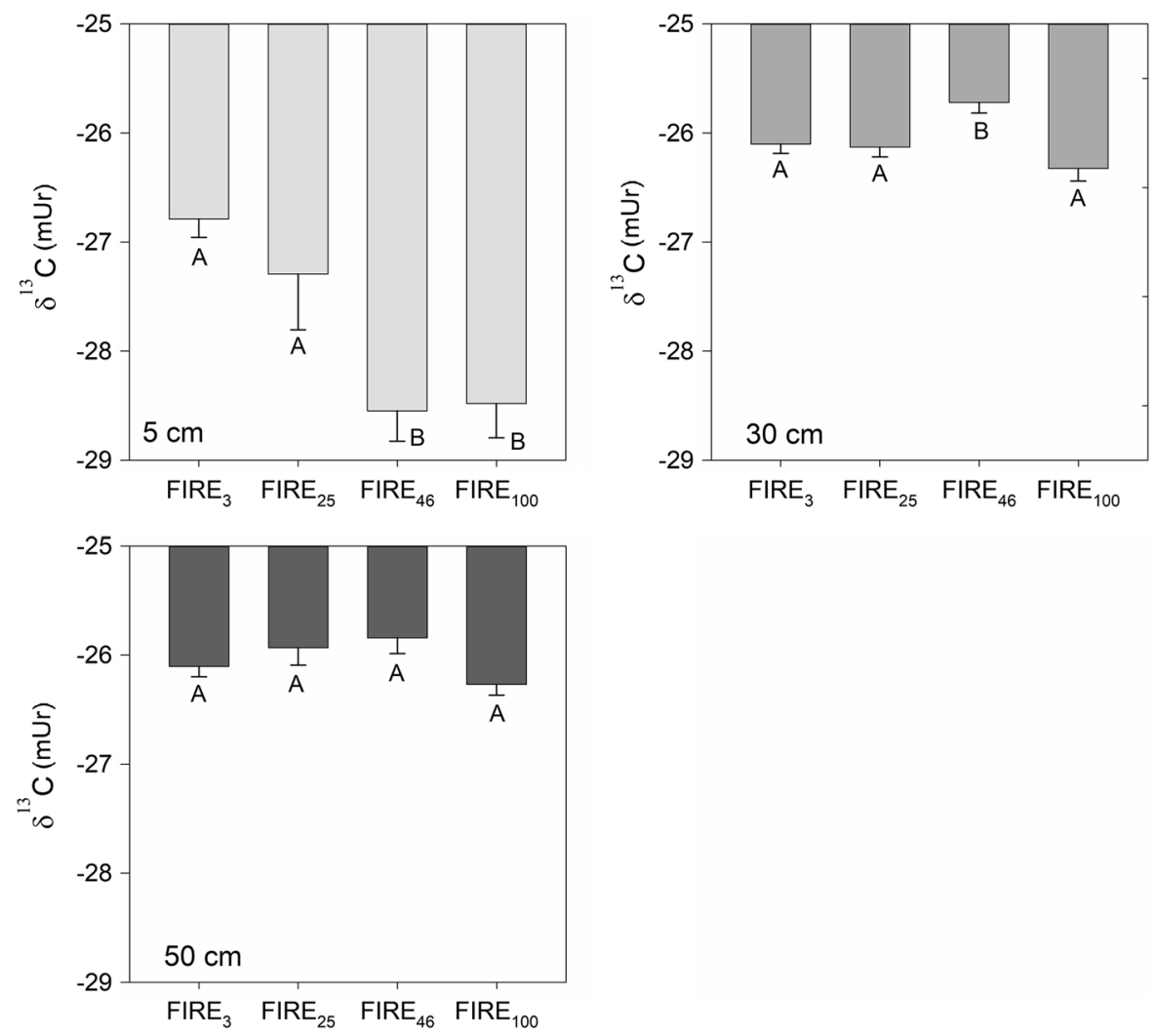

(Century manual). For example, Bot and Benites (2005) have allocated different SOM groups to three pools: sugars, as easily decomposing, could be placed in the active cycling pool, while fats, waxes and cellulose represent the slow pool. Lignins, as resistant compounds, form the stable SOM pool (Bot and Benites 2005; Kutsch et al. 2009). Though these pools may not be straightforwardly comparable to the pools used in CENTURY, it can be deduced that there is a vast difference in the decomposition rates of these different SOM pools. Further, the degradability of a compound is affected by its molecular weight and structure: material with low molecular weight (e.g. sugars, aminoacids, phenols) is easier to decompose than material with high molecular weight (e.g. cellulose, lignin, cutin) (Cotrufo et al. 2013). SOM that is most readily available is characterised by its solubility to water (Marschner and Kalbitz 2003).

We observed no significant changes with time after fire in the insoluble fraction. In case of fire chronosequences, in an early succession forest (recently burnt) there may be a higher proportion of recalcitrant (charred) SOM (González-Pérez et al. 2004; Wardle et al. 2008) as the organic layer may have been at least partially burnt. In late succession stage forests, on the other hand, incoming plant material, such as evergreen needles and woody material, is generally less easily decomposable (Brassard and Chen 2006). In our previous study, conducted in the same areas as this study, we observed that the organic layer depth continued to increase several decades after fire (Köster et al. 2017). Also the vegetation cover, both biomass and species composition, was affected by time since fire (Table S2, Online Resource). The youngest fire area had visible ashy, bare patches of ground, no living trees, less mosses and ground vegetation mostly consisting of Equisetum sylvaticum L. The older areas FIRE $_{46}$ and FIRE 100 (Table S2, Online Resource) had more lichen, mosses (Sphagnum sp., Pleurozium sp), shrubs (Ledum groenlandicum Oeder, Vaccinium vitis-idaea L., V. Uliginosum and some Rubus camaemorus L.) and mature trees (Köster et al. 2017). The area $\mathrm{FIRE}_{25}$ was similar to these, but with some remaining unvegetated patches and Cladonia and Cladina lichens. These changes in vegetation cover affect the quality of incoming organic matter to 
soil, thus affecting also the different proportions of SOM fractions. This is because different species have differing decomposition rates. Such shrubs as Vaccinium vitis-idaea and Rubus camaemorus L. decompose relatively slowly (Nilsson and Wardle 2005), while Equisetum sp species might decompose faster (Marsh et al. 2000). Further, though mosses decompose slowly, they have been observed to advance decomposition of other species by keeping up moisture levels in the litter layer (Wardle et al. 2003). Thus, in both recently burnt and late succession stage forests, there are possibly more sources for recalcitrant SOM than in mid-succession forests, perhaps explaining why we observed no significant changes with time in the insoluble fraction. We detected a trend (at $5 \mathrm{~cm}$ depth) of increasing proportions of recalcitrant SOM in younger, more recently burnt areas, indicating a strong effect of fire on SOM quality. Thus, charred SOM could have a noticeable role at some point in time. However, in an early succession forest, the input of resistant material may also be counteracted by the easily decomposable plant material deriving from the herbaceous plant species in the early succession stage (Chen and Shrestha 2012) or perhaps from the decomposing root material.

In the labile fractions (water and ethanol) the most obvious changes were observed at $5 \mathrm{~cm}$ soil depth. FIRE $_{3}$ and FIRE 100 did not show differences in the size of the water-soluble fraction, but the middle-aged fire areas had higher fractions of water-soluble SOM. The similarity between FIRE $_{3}$ and FIRE 100 is probably related to the previously mentioned succession dynamics. Alternatively, there could be greater leaching, or loss as run-off, of water-soluble SOM in these areas compared to FIRE $_{25}$ and FIRE $_{46}$. In area FIRE 3 there was probably less evapotranspiration than in older fire areas due to smaller transpiring leaf biomass. This could mean that a proportionally larger amount of water is moving down in the soil profile compared to the older forests, where vertical movement is also limited by the higher permafrost surface. Further, some pyrogenic compounds are actually water-soluble (Norwood et al. 2013) and might show in the watersoluble fraction in addition to sugars. However, this trend was different in the ethanol soluble fraction. Both FIRE $_{3}$ and FIRE $_{25}$ had smaller ethanol-soluble fractions than FIRE $_{46}$ and FIRE $_{100}$, meaning that waxes and fats form a greater proportion of SOM during the later succession. This is probably also related to changes in vegetation during the succession. In the later stage of forest succession, there is an increased biomass of coniferous trees and shrubs, with large amount of waxes in their cuticula, (Dickinson 1974; Brassard and Chen 2006), thus producing litter which increases the amount of fat and waxes in the SOM.

The fraction of insoluble SOM was higher in the 30 and $50 \mathrm{~cm}$ soil layers, which could be expected as deeper soils typically contains less readily decomposable SOM (Trumbore 2014). In addition, studies on black carbon have shown it to be easily translocated vertically in the soil and therefore it may have accumulated into subsoils (Dai et al. 2005; Rumpel et al. 2009). On the other hand, the ratios of SOM fractions are not only dependent on the formation of resistant compounds but are greatly affected by decomposers. Fungal species have an important role in degrading lignin (Waldrop et al. 2010). It has been found that if the fungal community becomes wiped out or reduced during the fire, the degradation of lignin will decrease (Waldrop et al. 2010), meaning that it could reside in the soil for a longer period. This could be apparent in the size of the insoluble SOM fraction for some time after the fire as Klason lignin found here is included in the recalcitrant fraction. For example, it takes several decades for the fungal biomass to recover after fire (Köster et al. 2016; Zhou et al. 2018). Yet we found that the length of time after fire had only a tendential, but insignificant, effect on the amount of insoluble and acid-soluble SOM, and can thus only speculate here about the role of fungi.

Our results show that the effects of fire on SOM are most prominent at the soil surface. The SOM fractions and isotopes showed very small, or no, differences between fire ages at $50 \mathrm{~cm}$ depth. This was further supported by the mixed effects model, where none of the predicting factors seemed to be significant and the only variable surviving to the best model was $\mathrm{C} / \mathrm{N}$ ratio. Contrastingly, at both 5 and $30 \mathrm{~cm}$ depths the best model included biomass (trees, shrubs, grasses, mosses and lichens), and both models were most sensitive to changes in biomass. As the biomass in the model included above ground (tree- and ground vegetation), it could be that changes in them reached the 5 and $30 \mathrm{~cm}$ depths but not $50 \mathrm{~cm}$. The effect of biomass on the size of the insoluble SOM fraction might occur through at least two opposing processes: loss of biomass during the forest fire and, on the other 
hand, an increase of biomass and changes in litter quality with succession (Brassard and Chen 2006). At $5 \mathrm{~cm}$, the effect of active layer depth on the insoluble SOM fraction was close to that of the biomass (Fig, S1, Online resource), which could be related to possible temperature changes caused by retreating/returning permafrost and the consequent effects on vegetation. At $30 \mathrm{~cm}$ depth the effect of the $\mathrm{C} / \mathrm{N}$ ratio was also close to that of biomass, possibly linking these two together as $\mathrm{C} / \mathrm{N}$ ratio is also an indicator of incoming litter quality (Johnson and Wedin 1997). Both biomass and $\mathrm{C} / \mathrm{N}$ ratio correlated negatively with the size of the insoluble SOM fraction. Still, the lack of explaining factors at $50 \mathrm{~cm}$ is perhaps connected to the proximity of permafrost or high soil water content.

The mixed effects model analysis further showed that microbial biomass is, amongst the SOM fractions, best predicted by the size of the insoluble fraction (at 5 and $30 \mathrm{~cm}$ depth). Moreover, microbial biomass and insoluble fraction size appear to correlate negatively, so that when the size of the insoluble fraction is high, the microbial biomass is low. This indicates that SOM quality is more important than SOM quantity in northern boreal ecosystem, as microbes usually prefer labile SOM fractions as a $\mathrm{C}$ source (Rinkes et al. 2011). Microbial biomass at $50 \mathrm{~cm}$ depth, on the other hand, is probably limited by factor other than the availability of labile SOM, such as soil temperature, the presence of permafrost and anoxic conditions due to a high ground water table on top of the permafrost (Hobbie et al. 2000b).

We discovered an age-related trend for $\delta^{15} \mathrm{~N}$, with the most recently burnt area having a more enriched surface soil than area FIRE 100 . During a fire, the ${ }^{15} \mathrm{~N}$ depleted litter layer may burn almost completely, rendering the burnt area with material enriched with ${ }^{15} \mathrm{~N}$ (Högberg 1997). For example, leaf litter of conifer trees seems to commonly be ${ }^{15} \mathrm{~N}$ depleted (Hobbie et al. 2000a; Sah and Ilvesniemi 2007). Usually plants that do not fix $\mathrm{N}_{2}$ have higher $\delta^{15} \mathrm{~N}$ values than plants fixing $\mathrm{N}_{2}$ (He et al. 2009) and differences in leaf $\delta^{15} \mathrm{~N}$ values are caused by discrimination against heavier isotopes in $\mathrm{N}$ uptake and transfer from mycorrhiza to plant (Hobbie and Hobbie 2006, 2008). The discrimination is also affected by the type of mycorrhiza (Michelsen et al. 1998), which might become apparent after such disturbances, as fire, where microbial species compositions are possibly altered. A change in the species composition was discovered also in this same fire chronosequence by Zhou et al. (2018). Previous studies have also noted that burning of the depleted litter is not necessarily the most dominating reason for enrichment with heavier isotopes. Instead, the enrichment may be attributed to volatilisation processes, which discriminate against heavier isotopes (Cook 2001; Boeckx et al. 2005) and root activity (Pumpanen et al. 2017). Forest fires generally also increase N leaching (Lamontagne et al. 2000), especially the leaching of ${ }^{15} \mathrm{~N}$ depleted $\mathrm{NO}_{3-}$ (Pardo et al. 2002), which may have contributed to ${ }^{15} \mathrm{~N}$ enrichment in the $\mathrm{FIRE}_{3}$ area. On the other hand, water-soluble pyrogenic compounds might also be enriched with ${ }^{15} \mathrm{~N}$ and translocating down the soil profile. The soil ${ }^{15} \mathrm{~N}$ enrichment tends to increase with soil depth (Högberg 1997), as a result of microbial degradation of SOM (ammonification, nitrification and denitrification processes), where enriched material is accumulating in the residues (Makarov 2009; Girona-García et al. 2018). Fire has also been shown to decrease the differences in ${ }^{15} \mathrm{~N}$ enrichment along the soil profile, by causing enrichment in the upper $20 \mathrm{~cm}$ (Boeckx et al. 2005); a trend that was also somewhat apparent in our results. ${ }^{15} \mathrm{~N}$ was enriched throughout the soil profile in area $\mathrm{FIRE}_{3}$, while older fire areas were slightly depleted at the surface and enriched in the two deepest layers. However, as these differences were so small that they were not statistically significant, it is not possible to make conclusions based on them.

A similar trend as for ${ }^{15} \mathrm{~N}$ was also found for ${ }^{13} \mathrm{C}$ abundance, with the two most recently burnt fire areas having less depleted values in the surface soil $(5 \mathrm{~cm})$ than in areas FIRE $_{100}$ and FIRE $_{46}$. Here we also noticed a trend where the ${ }^{13} \mathrm{C}$ enrichment increased with depth, which has been detected quite commonly across ecosystems (Brüggemann et al. 2011). Typically, higher $\delta^{13} \mathrm{C}$ values indicate the presence of ${ }^{13} \mathrm{C}$ enriched compounds, such as polysaccharides and amino acids, whereas ${ }^{13} \mathrm{C}$ depletion could be caused by the existence of depleted materials, such as lignin and lipids (Rumpel and Kögel-Knabner 2011). The leaf isotopic values of C3 plants generally average around - $27 \mathrm{mUr}$ (Brodribb and Hill 1998; Cernusak et al. 2009; Orchard et al. 2010), whereas lipids and lignin tend to be $-2 \mathrm{mUr}$ to $-3 \mathrm{mUr}$ more depleted compared to average leaf isotope value (Ehleringer et al. 2000). Cellulose tends to have similar, or slightly higher (Loader et al. 2003), values as lignin (Hobbie and Werner 2004). Some studies have found that 
during fire, cellulose is lost more than lignin and lipids, leading to lower $\delta{ }^{13} \mathrm{C}$ values in the heat modified $\mathrm{OM}$ (Alexis et al. 2010). On the other hand, post-fire litter of standing vegetation has been found to have higher $\delta$ ${ }^{13} \mathrm{C}$ values than pre-fire litter, with post-fire litter forming much of the pyrogenic material (Alexis et al. 2010). Both of these factors may have contributed to the changes observed in the $\delta{ }^{13} \mathrm{C}$ values in this study. For example, in the top $5 \mathrm{~cm}$, older fire areas had larger ethanol-soluble fraction (lipids etc.) and were more depleted. These findings seem to support each other and indicate that as succession proceeds after the fire, the size of the relatively labile SOM fraction increases.

In depth-wise comparison of the bulk soil the surface $(5 \mathrm{~cm})$ was more depleted of ${ }^{13} \mathrm{C}$ than the deeper layers (30 and $50 \mathrm{~cm}$ ), which seems to be the norm with ${ }^{13} \mathrm{C}$ in forest soils (Balesdent et al. 1993; Krull et al. 2002; Boström et al. 2007). The slight enrichment along the depth profile is also supported by fractionation results, where deeper layers had greater recalcitrant SOM fractions. The ${ }^{13} \mathrm{C}$ enrichment with depth in forest soils has been connected to four different hypotheses: the Suess effect, microbial fractionation, microbial preference and soil mixing (Ehleringer et al. 2000). The Suess effect, depletion of atmospheric $\mathrm{CO}_{2}$ of ${ }^{13} \mathrm{C}$ caused by the burning of depleted fossil fuels (Balesdent et al. 1990; Trolier et al. 1996), could lead to older/deeper soil layers having less depleted ${ }^{13} \mathrm{C}$ values corresponding to atmospheric ${ }^{13} \mathrm{CO}_{2}$ values of that time (Ehleringer et al. 2000). On the other hand, microbial fractionation prefers lighter isotopes, leading to enrichment in the residual SOM (Natelhoffer and Fry 1988; Ehleringer et al. 2000), while microbial preference is related to which kind of substrates the microbes favor (Ehleringer et al. 2000). Finally, C mixing suggests that during a loss of soil $\mathrm{C}$ there is mixing between fresh and old SOM, therefore causing changes in ${ }^{13} \mathrm{C}$ values. In addition to these, the $\mathrm{SOM}{ }^{13} \mathrm{C}$ values are much dependent on the origins of the material, such as type of litter (Benner et al. 1987). Regardless of the reason, in our results, the differences in ${ }^{13} \mathrm{C}$ values between the surface and deeper layers were not very large, which could be at least partly explained by possible enrichment at the surface after the fire. At the same time, in the two oldest fire areas the deepest $(50 \mathrm{~cm})$ samples were below the permafrost, seemingly indicating that permafrost $\mathrm{SOM}$ in this area is relatively recalcitrant.

Our results indicated that fires do decrease the quality of SOM in the surface layer, but that the effect of fire on soil at the permafrost surface is more indirect and happens through changes in soil temperature and deepening of the active layer. In the oldest fire areas, FIRE $_{46}$ and FIRE $_{100}$, the $50 \mathrm{~cm}$ (also $30 \mathrm{~cm}$ for FIRE $_{100}$ ) sampling depth was below the permafrost surface, showing that the permafrost soils in these areas were mostly very recalcitrant SOM and generally did not differ from the non-permafrost samples of the younger fire areas. While other studies have found somewhat differing results for the quality of permafrost SOM (Dutta et al. 2006; Waldrop et al. 2010; Moni et al. 2015), direct comparisons are difficult to make since there are differences between study sites, sampling depths and methods. As we did not sample the deep permafrost soils, some caution also needs to be taken while interpreting the results. However, our results indicated that, while in our study areas the permafrost may thaw, most of the permafrost SOM will possibly reside in the soil for a long period, due to its recalcitrant nature. Moreover, based on the sensitivity analyses, the permafrost/permafrost-affected soil does not seem to be very sensitive to changes, as the size of the recalcitrant fraction did not change significantly even if the factors affecting decomposition were changed in the sensitivity analysis of our linear mixed effect models. Despite this, it is possible that some of this recalcitrant SOM could decompose, as the input of fresh, easily decomposable $\mathrm{C}$ caused by fire could have a priming effect (Fontaine et al. 2007). Recalcitrant SOM may also be more temperature sensitive (Davidson and Janssens 2006; Karhu et al. 2010), unless protected by physical protection (Gillabel et al. 2010), meaning that the possible warming of soil, if the insulating organic layer is burnt and permafrost starts to thaw, may cause $\mathrm{C}$ emissions. Indeed, deeper active layer was found at the more recently burnt areas, which hints in that direction. Still, the formation of recalcitrant SOM by fire may act as a counter-affecting process. Possible C losses from these upland mineral forest soils are then largely dependent on whether in the warming climate the permafrost, lost after the fire, will continue to return as succession proceeds, and whether some following process will be able to degrade the potentially very resistant permafrost SOM. 
Based on our results the effect of fires on SOM quality seems to be mostly on the surface soil. Initially after fire, the surface soil SOM quality is reduced and, as succession proceeds, the ratios of the SOM fractions revert towards pre-fire status. The SOM in permafrost soils in these forest areas seem to be mostly recalcitrant. These indicate that even if permafrost thaws, the scale and rate of $\mathrm{C}$ emissions from the upland mineral permafrost soils could be limited. However, further research is needed for quantifying the amount of SOM in different fractions and assessing the SOM quality of deep permafrost soils.

We conclude that a consequence of changing climate is that fire intervals become shorter and the forest rotation time is decreased, leading to less $\mathrm{C}$ being stored in the soil (Kaipainen et al. 2004; Hoy et al. 2016). While labile $C$ is lost in fires, pyrogenic $C$ is accumulated to the soil. At the same time, the pioneer species in vegetation might prosper relatively longer times compared to late succession species, which affects the quality of SOM via incoming litter. These factors may be seen in a proportional decrease in the size of the labile SOM fraction and increase in the size of recalcitrant fraction: while labile $\mathrm{C}$ is lost in fire, pyrogenic $\mathrm{C}$ is stored. This might lead to decrease in $\mathrm{CO}_{2}$ emissions to the atmosphere from post-fire soil decomposition. At the same time, the permafrost has less time to recover and reach original depths (Hoy et al. 2016), meaning that the permafrost SOM, though possibly recalcitrant, will be vulnerable to decomposition for longer periods of time. The effect of these counteracting processes on permafrost $\mathrm{C}$ pools require further studies.

Acknowledgements Open access funding provided by University of Helsinki including Helsinki University Central Hospital. We sincerely thank Anu Riikonen for valuable assistance with the soil fractionation and Jenie Gil Lugo for conducting the isotope analyses. Financial support was provided by Academy of Finland (Projects Nos. 286685, 294600, 307222, 291691) and the BIOCHAR-project funded by the Finnish Foundation for Natural Resources (Suomen Luonnonvarain tutkimussäätiö).

Open Access This article is distributed under the terms of the Creative Commons Attribution 4.0 International License (http:// creativecommons.org/licenses/by/4.0/), which permits unrestricted use, distribution, and reproduction in any medium, provided you give appropriate credit to the original author(s) and the source, provide a link to the Creative Commons license, and indicate if changes were made.

\section{References}

Alexis MA, Rumpel C, Knicker H et al (2010) Thermal alteration of organic matter during a shrubland fire: a field study. Org Geochem 41:690-697. https://doi.org/10.1016/ j.orggeochem.2010.03.003

Almendros G, González-Vila FJ (2012) Wildfires, soil carbon balance and resilient organic matter in Mediterranean ecosystems. A review. SJSS Span J Soil Sci Year. https:// doi.org/10.3232/sjss.2012.v2.n2.01

Almendros G, Leal JA (1990) An evaluation of some oxidative degradation methods of humic substances applied to carbohydrate-derived humic-like polymers. J Soil Sci 41:51-59. https://doi.org/10.1111/j.1365-2389.1990. tb00044.x

Balesdent J, Mariotti A, Boisgontier D (1990) Effect of tillage on soil organic carbon mineralization estimated from ${ }^{13} \mathrm{C}$ abundance in maize fields. J Soil Sci 41:587-596. https:// doi.org/10.1111/j.1365-2389.1990.tb00228.x

Balesdent J, Girardin C, Mariotti A (1993) Site-related ${ }^{13} \mathrm{C}$ of tree leaves and soil organic matter in a temperate forest. Ecology 74:1713-1721. https://doi.org/10.2307/1939930

Bates D, Mächler M, Bolker B, Walker S (2015) Fitting linear mixed-effects models using lme4. J Stat Softw 67:1-48. https://doi.org/10.18637/jss.v067.i01

Beck T, Joergensen RG, Kandeler R et al (1997) An inter-laboratory comparison of ten different ways of measuring soil microbial biomass C. Soil Biol Biochem 29:1023-1032. https://doi.org/10.1016/S0038-0717(97)00030-8

Benner R, Fogel ML, Sprague EK, Hodson RE (1987) Depletion of $\mathrm{C}$ in lignin and its implications for stable carbon isotope studies. Nature 329:708-710. https://doi.org/10.1038/ $329708 \mathrm{a} 0$

Berg B, Ekbohm G (1991) Litter mass-loss rates patterns in some needle and leaf litter types. Long-term decomposition in a Scots pine forest. VII. Can J Bot 69:1449-1456

Berg B, McClaugherty C (2003) Plant litter: decomposition, humus formation, carbon sequestration. Springer, Berlin, p 286

Beuning KR, Scott JE (2002) Effects of charring on the carbon isotopic composition of grass (Poaceae) epidermis. Palaeogeogr Palaeoclimatol Palaeoecol 177:169-181. https://doi.org/10.1016/S0031-0182(01)00358-3

Boeckx P, Paulino L, Oyarzún C et al (2005) Soil $\delta 15$ N patterns in old-growth forests of southern Chile as integrator for N-cycling. Isotopes Environ Health Stud 41:249-259. https://doi.org/10.1080/10256010500230171

Boström B, Comstedt D, Ekblad A (2007) Isotope fractionation and $13 \mathrm{C}$ enrichment in soil profiles during the decomposition of soil organic matter. Oecologia 153:89-98. https:// doi.org/10.1007/s00442-007-0700-8

Bot A, Benites J (2005) The importance of soil organic matter key to drought-resistant soil and sustained crop production. FAO Soils Bulletin, Rome

Brassard BW, Chen HYH (2006) Stand structural dynamics of North American boreal forests. CRC Crit Rev Plant Sci 25:115-137. https://doi.org/10.1080/07352680500348857

Bret-Harte MS, Mack MC, Shaver GR et al (2013) The response of Arctic vegetation and soils following an unusually severe tundra fire. Philos Trans R Soc B Biol Sci 
368:20120490-20120490. https://doi.org/10.1098/rstb. 2012.0490

Brodribb T, Hill RS (1998) The photosynthetic drought physiology of a diverse group of southern hemisphere conifer species is correlated with minimum seasonal rainfall. Funct Ecol 12:465-471. https://doi.org/10.1046/j.1365-2435. 1998.00213.x

Brown DRN, Jorgenson MT, Douglas TA et al (2015) Interactive effects of wildfire and climate on permafrost degradation in Alaskan lowland forests. J Geophys Res Biogeosci 120:1619-1637. https://doi.org/10.1002/ 2015JG003033

Brüggemann N, Gessler A, Kayler Z, Keel SG et al (2011) Carbon allocation and carbon isotope fluxes in the plantsoil-atmosphere continuum: a review. Biogeosciences 8:3457-3489. https://doi.org/10.5194/bg-8-3457-2011

CENTURY Soil Organic Matter Model Environment. https:// www2.nrel.colostate.edu/projects/century/MANUAL/ html_manual/man96.html\#CENTOVER. Accessed 7 Nov 2018

Cernusak LA, Tcherkez G, Keitel C et al (2009) Why are nonphotosynthetic tissues generally ${ }^{13} \mathrm{C}$ enriched compared with leaves in $\mathrm{C}_{3}$ plants? Review and synthesis of current hypotheses. Funct Plant Biol 36:199. https://doi.org/10. 1071/FP08216

Certini G (2005) Effects of fire on properties of forest soils: a review. Oecologia 143:1-10. https://doi.org/10.1007/ s00442-004-1788-8

Certini G, Nocentini C, Knicker H et al (2011) Wildfire effects on soil organic matter quantity and quality in two fire-prone Mediterranean pine forests. Geoderma 167-168:148-155. https://doi.org/10.1016/j.geoderma.2011.09.005

Chambers JM, Hastie T (1992) Statistical models in S. Wadsworth \& Brooks/Cole Advanced Books \& Software, Monterey, CA

Chen HYH, Shrestha BM (2012) Stand age, fire and clearcutting affect soil organic carbon and aggregation of mineral soils in boreal forests. Soil Biol Biochem 50:149-157. https:// doi.org/10.1016/J.SOILBIO.2012.03.014

Cook GD (2001) Effects of frequent fires and grazing on stable nitrogen isotope ratios of vegetation in northern Australia. Austral Ecol 26:630-636. https://doi.org/10. 1046/j.1442-9993.2001.01150.x

Cotrufo MF, Wallenstein MD, Boot CM et al (2013) The microbial efficiency-matrix stabilization (MEMS) framework integrates plant litter decomposition with soil organic matter stabilization: do labile plant inputs form stable soil organic matter? Glob Chang Biol 19:988-995. https://doi. org/10.1111/gcb.12113

Czimczik CI, Preston CM, Schmidt MWI, Schulze E-D (2003) How surface fire in Siberian Scots pine forests affects soil organic carbon in the forest floor: stocks, molecular structure, and conversion to black carbon (charcoal). Global Biogeochem Cycles. https://doi.org/10.1029/ $2002 \mathrm{gb} 001956$

Dai X, Boutton TW, Glaser B et al (2005) Black carbon in a temperate mixed-grass savanna. Soil Biol Biochem 37:1879-1881. https://doi.org/10.1016/j.soilbio.2005.02. 021

Davidson EA, Janssens IA (2006) Temperature sensitivity of soil carbon decomposition and feedbacks to climate change. Nature 440:165-173. https://doi.org/10.1038/ nature 04514

De la Rosa JM, González-Pérez JA, González-Vila FJ, Knicker $\mathrm{H}$ (2013) Medium term effects of fire induced soil organic matter alterations on Andosols under Canarian pine (Pinus canariensis). J Anal Appl Pyrolysis 104:269-279. https:// doi.org/10.1016/J.JAAP.2013.07.006

DeBano L (2000) The role of fire and soil heating on water repellency in wildland environments: a review. J Hydrol 231-232:195-206. https://doi.org/10.1016/S00221694(00)00194-3

Debano LF, Conrad CE (1978) The effect of fire on nutrients in a Chaparral ecosystem. Ecology 59:489-497. https://doi.org/ $10.2307 / 1936579$

Dickinson CH (1974) Biology of plant litter decomposition V1. Elsevier Science, Amsterdam, p 422

Dooley SR, Treseder KK (2012) The effect of fire on microbial biomass: a meta-analysis of field studies. Biogeochemistry 109:49-61

Dutta K, Schuur EAG, Neff JC, Zimov SA (2006) Potential carbon release from permafrost soils of Northeastern Siberia. Glob Chang Biol 12:2336-2351. https://doi.org/ 10.1111/j.1365-2486.2006.01259.x

Ehleringer JR, Buchmann N, Flanagan LB (2000) Carbon isotope ratios in belowground carbon cycle processes. Ecol Appl 10:412-422. https://doi.org/10.1890/10510761(2000)010\%5b0412:CIRIBC\%5d2.0.CO;2

Environment and Climate Change Canada (2017) Canadian Climate Normals-Climate-Environment and Climate Change Canada. http://climate.weather.gc.ca/climate_ normals/index_e.html. Accessed 16 Jan 2018

Faria AF, Álvarez VVH, Mattiello EM et al (2012) Wildfires, soil carbon balance and resilient organic matter in Mediterranean ecosystems. A review. Universia. https:// doi.org/10.3232/SJSS.2012.V2.N2.01

Figueiredo K, Mäenpää K, Leppänen MT et al (2014) Trophic transfer of polychlorinated biphenyls (PCB) in a boreal lake ecosystem: testing of bioaccumulation models. Sci Total Environ 466-467:690-698. https://doi.org/10.1016/ J.SCITOTENV.2013.07.033

Flannigan M, Stocks B, Turetsky M, Wotton M (2009) Impacts of climate change on fire activity and fire management in the circumboreal forest. Glob Chang Biol 15:549-560. https://doi.org/10.1111/j.1365-2486.2008.01660.x

Fontaine S, Barot S, Barré P et al (2007) Stability of organic carbon in deep soil layers controlled by fresh carbon supply. Nature 450:277-280. https://doi.org/10.1038/ nature 06275

Frank DA, Evans RD, Tracy BF (2004) The role of ammonia volatilization in controlling the natural ${ }^{15} \mathrm{~N}$ abundance of a grazed grassland. Biogeochemistry 68:169-178. https:// doi.org/10.1023/B:BIOG.0000025736.19381.91

French NHF, Whitley MA, Jenkins LK (2016) Fire disturbance effects on land surface albedo in Alaskan tundra. J Geophys Res Biogeosciences 121:841-854. https://doi.org/10.1002/ 2015JG003177

Gentsch N, Mikutta R, Alves RJE et al (2015) Storage and transformation of organic matter fractions in cryoturbated permafrost soils across the Siberian Arctic. Biogeosciences 12:4525-4542. https://doi.org/10.5194/bg-12-4525-2015 
Gibson CM, Chasmer LE, Thompson DK et al (2018) Wildfire as a major driver of recent permafrost thaw in boreal peatlands. Nat Commun 9:3041. https://doi.org/10.1038/ s41467-018-05457-1

Gill HK, Lantzx TC, O’Neill B, Kokelj SV (2014) Cumulative Impacts and Feedbacks of a Gravel Road on Shrub Tundra Ecosystems in the Peel Plateau, Northwest Territories, Canada. Arctic Antarct Alp Res 46:947-961. https://doi. org/10.1657/1938-4246-46.4.947

Gillabel J, Cebrian-Lopez B, Six J, Merckx R (2010) Experimental evidence for the attenuating effect of SOM protection on temperature sensitivity of SOM decomposition. Glob Chang Biol 16:2789-2798. https://doi.org/10.1111/j. 1365-2486.2009.02132.x

Girona-García A, Badía-Villas D, Jiménez-Morillo NT et al (2018) Soil C and N isotope composition after a centennial Scots pine afforestation in podzols of native European beech forests in NE-Spain. CATENA 165:434-441. https://doi.org/10.1016/j.catena.2018.02.023

González-Pérez JA, González-Vila FJ, Almendros G, Knicker H (2004) The effect of fire on soil organic matter-a review. Environ Int 30:855-870. https://doi.org/10.1016/j.envint. 2004.02.003

Harden JW, Koven CD, Ping C-L et al (2012) Field information links permafrost carbon to physical vulnerabilities of thawing. Geophys Res Lett. https://doi.org/10.1029/ $2012 \mathrm{~g} 1051958$

He X, Xu M, Qiu GY, Zhou J (2009) Use of ${ }^{15} \mathrm{~N}$ stable isotope to quantify nitrogen transfer between mycorrhizal plants. J Plant Ecol 2:107-118. https://doi.org/10.1093/jpe/rtp015

Helbig M, Pappas C, Sonnentag O (2016) Permafrost thaw and wildfire: equally important drivers of boreal tree cover changes in the Taiga Plains, Canada. Geophys Res Lett 43:1598-1606. https://doi.org/10.1002/2015g1067193

Hobbie JE, Hobbie EA (2006) ${ }^{15} \mathrm{~N}$ in symbiotic fungi and plants estimates nitrogen and carbon flux rates in Arctic tundra. Ecology 87:816-822

Hobbie EA, Hobbie JE (2008) Natural abundance of ${ }^{15} \mathrm{~N}$ in nitrogen-limited forests and tundra can estimate nitrogen cycling through mycorrhizal fungi: a review. Ecosystems 11:815-830. https://doi.org/10.1007/s10021-008-9159-7

Hobbie E, Werner RA (2004) Intramolecular, compoundspecific, and bulk carbon isotope patterns in $\mathrm{C}_{3}$ and $\mathrm{C}_{4}$ plants: a review and synthesis. New Phytol 161:371-385. https://doi.org/10.1111/j.1469-8137.2004.00970.x

Hobbie EA, Macko SA, Williams M (2000a) Correlations between foliar $\delta^{15} \mathrm{~N}$ and nitrogen concentrations may indicate plant-mycorrhizal interactions. Oecologia 122:273-283. https://doi.org/10.1007/PL00008856

Hobbie SE, Schimel JP, Trumbore SE, Randerson JR (2000b) Controls over carbon storage and turnover in high-latitude soils. Glob Chang Biol 6:196-210. https://doi.org/10.1046/ j.1365-2486.2000.06021.x

Höfle S, Rethemeyer J, Mueller CW, John S (2013) Organic matter composition and stabilization in a polygonal tundra soil of the Lena Delta. Biogeosciences. https://doi.org/10. 5194/bg-10-3145-2013

Högberg P (1997) ${ }^{15} \mathrm{~N}$ natural abundance in soil-plant systems. New Phytol 57:179-203

Hoy EE, Turetsky MR, Kasischke ES (2016) More frequent burning increases vulnerability of Alaskan boreal black spruce forests. Environ Res Lett 11:095001. https://doi. org/10.1088/1748-9326/11/9/095001

Hyodo F, Kusaka S, Wardle DA, Nilsson M-C (2013) Changes in stable nitrogen and carbon isotope ratios of plants and soil across a boreal forest fire chronosequence. Plant Soil. https://doi.org/10.1007/s11104-012-1339-8

IUSS Working Group WRB (2014) World reference base for soil resources 2014. International soil classification system for naming soils and creating legends for soil maps

Johnson NC, Wedin DA (1997) Soil carbon, nutrients and mycorhizae during conversion of dry tropical forest to grassland. Ecol Appl 7(1):171-182. https://doi.org/10. 1890/1051-0761(1997)007\%5b0171:SCNAMD\%5d2.0. $\mathrm{CO} ; 2$

Jorgenson MT, Romanovsky V, Harden J et al (2010) Resilience and vulnerability of permafrost to climate changeThis article is one of a selection of papers from the dynamics of change in Alaska's Boreal forests: resilience and vulnerability in response to climate warming. Can J For Res 40:1219-1236. https://doi.org/10.1139/X10-060

Kaipainen T, Liski J, Pussinen A, Karjalainen T (2004) Managing carbon sinks by changing rotation length in European forests. Environ Sci Policy 7:205-219. https:// doi.org/10.1016/j.envsci.2004.03.001

Karhu K, Fritze H, Tuomi M et al (2010) Temperature sensitivity of organic matter decomposition in two boreal forest soil profiles. Soil Biol Biochem 42:72-82. https://doi.org/ 10.1016/j.soilbio.2009.10.002

Knicker H (2007) How does fire affect the nature and stability of soil organic nitrogen and carbon? A review. Biogeochemistry 85:91-118

Knicker H, Almendros G, González-Vila FJ et al (1996) ${ }^{13} \mathrm{C}$ and ${ }^{15} \mathrm{~N}-\mathrm{NMR}$ spectroscopic examination of the transformation of organic nitrogen in plant biomass during thermal treatment. Soil Biol Biochem 28:1053-1060. https://doi. org/10.1016/0038-0717(96)00078-8

Köster K, Berninger F, Heinonsalo J et al (2016) The long-term impact of low-intensity surface fires on litter decomposition and enzyme activities in boreal coniferous forests. Int $\mathbf{J}$ Wildl Fire. https://doi.org/10.1071/wf14217

Köster E, Köster K, Berninger F et al (2017) Carbon dioxide, methane and nitrous oxide fluxes from a fire chronosequence in subarctic boreal forests of Canada. Sci Total Environ 601-602:895-905. https://doi.org/10.1016/j. scitotenv.2017.05.246

Krull ES, Bestland EA, Gates WP (2002) Soil organic matter decomposition and turnover in a tropical ultisol: evidence from $\delta^{13} \mathrm{C}, \quad \delta^{15} \mathrm{~N}$ and geochemistry. Radiocarbon 44:93-112. https://doi.org/10.1017/S0033822200064705

Krull ES, Swanston CW, Skjemstad JO, McGowan JA (2006) Importance of charcoal in determining the age and chemistry of organic carbon in surface soils. J Geophys Res Biogeosci. https://doi.org/10.1029/2006jg000194

Kutsch W, Bahn M, Heinemeyer A (2009) Soil carbon dynamics : an integrated methodology. Cambridge University Press, Cambridge

Lambert M-C, Ung C-H, Raulier F (2005) Canadian national tree aboveground biomass equations. Can J For Res 35:1996-2018. https://doi.org/10.1139/x05-112

Lamontagne S, Carignan R, D'Arcy P et al (2000) Element export in runoff from eastern Canadian Boreal Shield 
drainage basins following forest harvesting and wildfires. Can J Fish Aquat Sci 57:118-128. https://doi.org/10.1139/ f00-108

Lawrence DM, Koven CD, Swenson SC et al (2015) Permafrost thaw and resulting soil moisture changes regulate projected high-latitude $\mathrm{CO}_{2}$ and $\mathrm{CH}_{4}$ emissions. Environ Res Lett 10:094011. https://doi.org/10.1088/1748-9326/10/9/ 094011

Liski J, Palosuo T, Peltoniemi M, Sievänen R (2005) Carbon and decomposition model Yasso for forest soils. Ecol Modell 189:168-182. https://doi.org/10.1016/J.ECOLMODEL. 2005.03.005

Loader NJ, Robertson I, McCarroll D (2003) Comparison of stable carbon isotope ratios in the whole wood, cellulose and lignin of oak tree-rings. Palaeogeogr Palaeoclimatol Palaeoecol 196:395-407. https://doi.org/10.1016/S00310182(03)00466-8

López-Martín M, Velasco-Molina M, Knicker H (2016) Variability of the quality and quantity of organic matter in soil affected by multiple wildfires. J Soils Sediments 16:360-370. https://doi.org/10.1007/s11368-015-1223-2

Makarov MI (2009) The nitrogen isotopic composition in soils and plants: its use in environmental studies (A Review). Eurasian Soil Sci 42:1335-1347. https://doi.org/10.1134/ S1064229309120035

Marschner B, Kalbitz K (2003) Controls of bioavailability and biodegradability of dissolved organic matter in soils. Geoderma 113:211-235. https://doi.org/10.1016/S00167061(02)00362-2

Marsh AS, Arnone JA, Bormann BT, Gordon JC (2000) The role of Equisetum in nutrient cycling in an Alaskan shrub wetland. J Ecol 88:999-1011. https://doi.org/10.1046/j. 1365-2745.2000.00520.x

Mataix-Solera J, Guerrero C, García-Orenes F et al (2009) Forest fire effects on soil microbiology. Fire Effects Soils Restor Strateg 5:133-175

Michelsen A, Quarmby C, Sleep D, Jonasson S (1998) Vascular plant ${ }^{15} \mathrm{~N}$ natural abundance in heath and forest tundra ecosystems is closely correlated with presence and type of mycorrhizal fungi in roots. Oecologia 115:406-418. https://doi.org/10.1007/s004420050535

Moni C, Lerch TZ, Knoth De Zarruk K et al (2015) Temperature response of soil organic matter mineralisation in arctic soil profiles. Soil Biol Biochem 88:236-246. https://doi.org/10. 1016/j.soilbio.2015.05.024

Natelhoffer KJ, Fry B (1988) Controls on natural nitrogen-15 and carbon-13 abundances in forest soil organic matter. Soil Sci Soc Am J 52:1633. https://doi.org/10.2136/ sssaj1988.03615995005200060024x

Nilsson M-C, Wardle DA (2005) Understory vegetation as a forest ecosystem driver: evidence from the northern Swedish boreal forest. Front Ecol Environ 3:421-428. https://doi.org/10.1890/1540-9295(2005)003\%5b0421: UVAAFE\% $5 \mathrm{~d} 2.0 . \mathrm{CO} ; 2$

Norwood MJ, Louchouarn P, Kuo L-J, Harvey OR (2013) Characterization and biodegradation of water-soluble biomarkers and organic carbon extracted from low temperature chars. Org Geochem 56:111-119. https://doi.org/ 10.1016/J.ORGGEOCHEM.2012.12.008

Orchard KA, Cernusak LA, Hutley LB (2010) Photosynthesis and water-use efficiency of seedlings from northern
Australian monsoon forest, savanna and swamp habitats grown in a common garden. Funct Plant Biol 37:1050. https://doi.org/10.1071/FP09306

Osman KT (2013) Soils : principles, properties and management. Springer, New York

Pardo LH, Hemond HF, Montoya JP et al (2002) N in forest soils and foliage to high nitrate loss following clear-cutting. Can J For Res 32:1126-1136. https://doi.org/10.1139/x02-041

Pumpanen J, Lindén A, Bruckman VJ et al (2017) The effect of roots and easily available carbon on the decomposition of soil organic matter fractions in boreal forest soil. Eur J Soil Sci 68:537-546. https://doi.org/10.1111/ejss.12439

Randerson JT, Liu H, Flanner MG et al (2006) The impact of boreal forest fire on climate warming. Science 314:1130-1132. https://doi.org/10.1126/science.1132075

Rinkes ZL, Weintraub MN, DeForest JL, Moorhead DL (2011) Microbial substrate preference and community dynamics during decomposition of Acer saccharum. Fungal Ecol 4:396-407. https://doi.org/10.1016/J.FUNECO.2011.01. 004

Rodríguez J, González-Pérez JA, Turmero A et al (2017) Wildfire effects on the microbial activity and diversity in a Mediterranean forest soil. CATENA 158:82-88. https:// doi.org/10.1016/j.catena.2017.06.018

Rodríguez J, González-Pérez JA, Turmero A et al (2018) Physico-chemical and microbial perturbations of Andalusian pine forest soils following a wildfire. Sci Total Environ 634:650-660. https://doi.org/10.1016/J.SCITOTENV. 2018.04.028

Rumpel C, Kögel-Knabner I (2011) Deep soil organic matter-a key but poorly understood component of terrestrial C cycle. Plant Soil 338:143-158. https://doi.org/10.1007/s11104010-0391-5

Rumpel C, González-Pérez JA, Bardoux G et al (2007) Composition and reactivity of morphologically distinct charred materials left after slash-and-burn practices in agricultural tropical soils. Org Geochem 38:911-920. https://doi.org/ 10.1016/j.orggeochem.2006.12.014

Rumpel C, Ba A, Darboux F et al (2009) Erosion budget and process selectivity of black carbon at meter scale. Geoderma 154:131-137. https://doi.org/10.1016/J. GEODERMA.2009.10.006

Sah SP, Ilvesniemi H (2007) Interspecific variation and impact of clear-cutting on natural ${ }^{15} \mathrm{~N}$ abundance and $\mathrm{N}$ concentration in the needle-to-soil continuum of a boreal conifer forest. Plant Soil Environ 53:329-339

Schädel C, Bader MK-F, Schuur EAG et al (2016) Potential carbon emissions dominated by carbon dioxide from thawed permafrost soils. Nat Clim Chang 6:950-953. https://doi.org/10.1038/nclimate3054

Shibata H, Petrone KC, Hinzman LD, Boone RD (2003) Effect of fire on dissolved organic carbon and inorganic solutes in spruce forest in the permafrost region of interior Alaska. Soil Sci Plant Nutr 49:25-29. https://doi.org/10.1080/ 00380768.2003.10409975

Stocks BJ, Alexander ME, Lanoville RA (2004) Overview of the International Crown Fire Modelling Experiment (ICFME). Can J For Res 34:1543-1547. https://doi.org/10.1139/x04905

Sukhinin AI, French NHF, Kasischke ES et al (2004) AVHRRbased mapping of fires in Russia: new products for fire 
management and carbon cycle studies. Remote Sens Environ 93:546-564. https://doi.org/10.1016/J.RSE.2004. 08.011

Tan Z, Tieszen LL, Zhu Z et al (2007) An estimate of carbon emissions from 2004 wildfires across Alaskan Yukon River Basin. Carbon Balance Manag 2:12. https://doi.org/10. 1186/1750-0680-2-12

Trofymow J, CIDET Working Group (1998) The Canadian Intersite Decomposition Experiment Project and Site Establishment Report

Trolier M, White JWC, Tans PP et al (1996) Monitoring the isotopic composition of atmospheric $\mathrm{CO}_{2}$ : measurements from the NOAA Global Air Sampling Network. J Geophys Res Atmos 101:25897-25916. https://doi.org/10.1029/ 96JD02363

Trumbore S (2014) Age of soil organic matter and soil respiration: radiocarbon constraints on belowground $\mathrm{C}$ dynamics. Ecol Appl 10:399-411. https://doi.org/10.1890/ 1051-0761(2000)010\%5b0399:AOSOMA\%5d2.0.CO;2

Trumbore SE, Harden JW (1997) Accumulation and turnover of carbon in organic and mineral soils of the BOREAS northern study area. Geophys Res 102:28817-28830

Tu K, Dawson G (2004) Partitioning ecosystem respiration using stable carbon isotope analysis of $\mathrm{CO} 2$. In: Flanagan LB, Ehleringer JR, Pataki DE, Mooney H (eds) Physiological ecology. Elsevier Academic, Amsterdam

Vance ED, Brookes PC, Jenkinson DS (1987) An extraction method for measuring soil microbial biomass C. Soil Biol Biochem 19:703-707. https://doi.org/10.1016/00380717(87)90052-6

Vitousek P, Howarth R (1991) Nitrogen limitation on land and in the sea: how can it occur? Biogeochemistry 13:87-115. https://doi.org/10.1007/BF00002772

Wagner RG, Ter-Mikaelian MT (1999) Comparison of biomass component equations for four species of northern coniferous tree seedlings. Ann For Sci 56:193-199. https://doi. org/10.1051/forest:19990301

Waldrop MP, Wickland KP, White R et al (2010) Molecular investigations into a globally important carbon pool: permafrost-protected carbon in Alaskan soils. Glob Chang Biol 16:2543-2554. https://doi.org/10.1111/j.1365-2486. 2009.02141.x
Walz J, Knoblauch C, Böhme L, Pfeiffer E-M (2017) Regulation of soil organic matter decomposition in permafrost-affected Siberian tundra soils - Impact of oxygen availability, freezing and thawing, temperature, and labile organic matter. Soil Biol Biochem 110:34-43. https://doi.org/10. 1016/j.soilbio.2017.03.001

Wan S, Hui D, Luo Y (2001) Fire effects on nitrogen pools and dynamics in terrestrial ecosystems: a meta-analysis. Ecol Appl 11:1349-1365. https://doi.org/10.1890/ 10510761(2001)011\%5b1349:FEONPA\%5d2.0.CO;2

Wardle DA, Nilsson M-C, Zackrisson O, Gallet C (2003) Determinants of litter mixing effects in a Swedish boreal forest. Soil Biol Biochem 35:827-835. https://doi.org/10. 1016/S0038-0717(03)00118-4

Wardle DA, Nilsson M-C, Zackrisson O (2008) Fire-derived charcoal causes loss of forest humus. Science 320:629. https://doi.org/10.1126/science. 1154960

Weiss N, Blok D, Elberling B et al (2016) Thermokarst dynamics and soil organic matter characteristics controlling initial carbon release from permafrost soils in the Siberian Yedoma region. Sediment Geol 340:38-48. https://doi.org/10.1016/J.SEDGEO.2015.12.004

Wynn JG (2007) Carbon isotope fractionation during decomposition of organic matter in soils and paleosols: implications for paleoecological interpretations of paleosols. Palaeogeogr Palaeoclimatol Palaeoecol 251:437-448. https://doi.org/10.1016/J.PALAEO.2007.04.009

Yoshikawa K, Bolton WR, Romanovsky VE et al (2002) Impacts of wildfire on the permafrost in the boreal forests of Interior Alaska. J Geophys Res 108:8148. https://doi. org/10.1029/2001JD000438

Zhou X, Sun H, Pumpanen J et al (2018) The impact of wildfire on microbial $\mathrm{C}: \mathrm{N}$ : P stoichiometry and the fungal-to-bacterial ratio in permafrost soil. Biogeochemistry. https://doi. org/10.1007/s10533-018-0510-6

Publisher's Note Springer Nature remains neutral with regard to jurisdictional claims in published maps and institutional affiliations. 